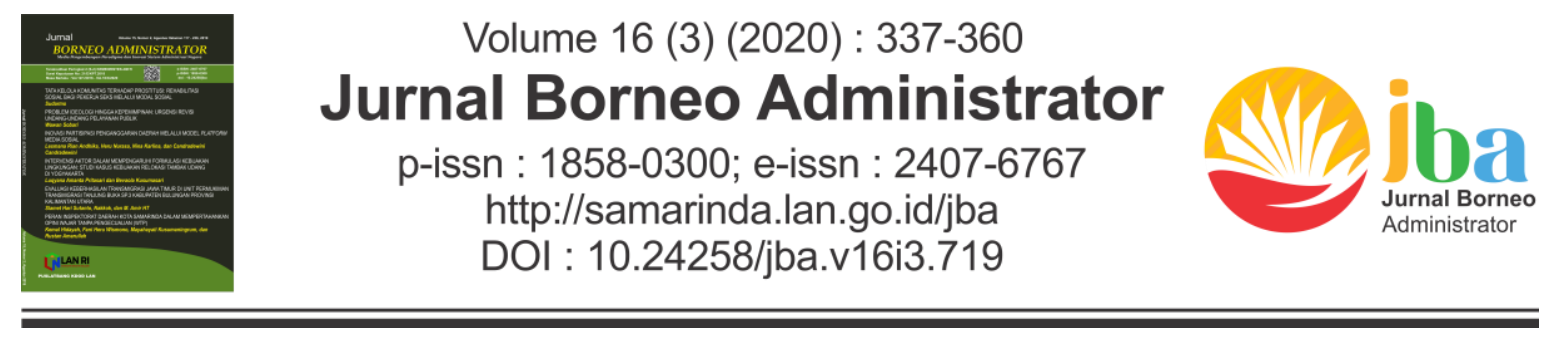

\title{
QUINTUPLE HELIX DAN MODEL DESA INOVATIF (STUDI KASUS INOVASI DESA DI DESA PANGGUNGHARJO, YOGYAKARTA)
}

\section{QUINTUPLE HELIX AND INNOVATIVE VILLAGE MODEL (A CASE STUDY OF VILLAGE INNOVATION IN PANGGUNGHARJO VILLAGE, YOGYAKARTA)}

\author{
Retnayu Prasetyanti dan Bayu Mitra A. Kusuma
}

\author{
Universitas Islam Negeri Sunan Kalijaga \\ Jl. Laksda Adisucipto, Papringan, Caturtunggal, Kec. Depok, \\ Kabupaten Sleman, Daerah Istimewa Yogyakarta \\ Email: retnayu.prasetyanti@gmail.com
}

Naskah diterima: 18 Juni 2020; revisi terakhir: 17 November 2020; disetujui: 14 Desember 2020 How to Cite: Prasetyanti, Retnayu dan Kusuma, Bayu Mitra A. (2020). Quintuple Helix dan Model Desa Inovatif (Studi Kasus Inovasi Desa di Desa Panggungharjo, Yogyakarta). Jurnal Borneo Administrator, 16 (3), 337-360. https://doi.org/10.24258/jba.v16i3.719

\begin{abstract}
Innovation determines the future of village development. This qualitative case study presents an analysis of village governance best practices in economic, environmental, socio-cultural, and technological aspects. Unlike the majority of villages that duplicate innovation, Panggungharjo was able to develop a genuine innovation through the creation of a village-owned enterprise (BUMDes). This scientific paper concludes that participation and synergy among helixes/subsystems in the quintuple helix innovation model (government, industry, universities, civil society, and the natural environment) determine the success of continuing village innovation. In Panggungharjo village, there were 3 affecting factors in succeeding innovation, there were political and leadership capacity; process and bureaucratic capacity; and social and environmental capacity. The use of the top-down \& bottom-up innovative village model was also crucial. As a lesson learned, this study formulated the stages of developing innovative villages. The figure of the village leader played a crucial role in the process of initiating innovation and optimizing the village bureaucracy politically and administratively. A set of development roadmap referring to the national priority of the village development program was fundamental. It is also urgent to maintain coordination among helixes so that village innovation can embrace the potential of the village and influence people's welfare.
\end{abstract}

Keywords: Quintuple Helix, Innovation Model, Village Innovation, Village Development, Innovative Village Model 


\begin{abstract}
Abstrak
Inovasi menjadi penentu arah kemajuan desa. Studi kasus kualitatif instrumental ini menyajikan analisis best practice tata kelola inovasi desa pada aspek ekonomi, lingkungan, sosial-budaya, dan teknologi. Berbeda dengan sebagian besar desa yang melakukan duplikasi inovasi, Desa Panggungharjo mampu mengembangkan inovasi secara mandiri melalui pembentukan BUMDes, sebuah lembaga ekonomi-sosial desa. Artikel ini menunjukkan bahwa partisipasi dan sinergi antarsubsistem dalam model inovasi quintuple helix (pemerintah, industri, universitas, masyarakat sipil, dan lingkungan alami) menjadi penentu keberhasilan inovasi desa yang berkelanjutan. Terdapat tiga faktor penentu keberhasilan inovasi, mengacu pada istilah Kepala Desa Panggungharjo, didefinisikan sebagai tiga kapasitas (kompetensi) utama, yaitu; (1) kapasitas politik dan kepemimpinan; (2) kapasitas proses dan birokrasi; (3) kapasitas sosial dan lingkungan. Aspek penting lain yang perlu diperhatikan adalah penerapan model desa inovatif berbasis pendekatan top-down \& bottom-up. Studi ini merumuskan tahapan pengembangan desa inovatif sebagai lesson learnt dari kesuksesan inovasi di Desa Panggungharjo. Sosok pemimpin desa memegang peran krusial terutama dalam proses inisiasi program inovasi dan optimalisasi birokrasi desa. Pemerintah desa dituntut untuk mampu menyusun roadmap perencanaan pembangunan desa sesuai arah kebijakan/program prioritas desa dalam lingkup nasional. Sebagai tindak lanjut, pengembangan inovasi harus didasarkan pada koordinasi dan penguatan jaringan kerja sama antar-helix sehingga dapat berimbas pada pemerataan kesejahteraan masyarakat.
\end{abstract}

Kata Kunci: Quintuple Helix, Model Inovasi, Inovasi Desa, Pembangunan Desa, Model Desa Inovatif

\title{
A. PENDAHULUAN
}

Dinamika model inovasi dan praktik inovasi pada sektor pemerintahan semakin berkembang sejalan dengan menguatnya era New Public Management (NPM) pada awal 90an. Merujuk pada buku karya Osborne dan Gaebler - "Reinventing Bureaucracy: How the Entrepreneurial Spirit is Transforming the Public Sector", paradigma NPM menjadi pelopor pola kerja customer-orientation yang memaksa birokrasi untuk beradaptasi dengan inovasi dan kompetisi (Osborne \& Gaebler, 1993). Budaya inovasi yang sebelumnya melekat pada prinsip kerja sektor swasta, saat ini telah menjadi nilai dasar dalam sektor publik, khususnya di era agile bureaucracy.

Transformasi tata kelola pemerintahan dan pembangunan secara masif dan konsisten mengusung inovasi berbasis teknologi. Sejak saat itu pula, di awal era 4.0, polemik governance dan pembangunan semakin kompleks, pemerintah dihadapkan dengan beragam peluang dan tantangan inovasi di berbagai lini. Pergeseran ritme kerja birokrasi berubah drastis. Revolusi industri 4.0 semakin memantapkan praktik e-government sebagai sebuah keniscayaan. Pada era ini, inovasi memampukan pemerintah, industri, dan masyarakat untuk tanggap terhadap perubahan (Pyburn \& Woodhill, 2015: 7). Sejalan dengan hal tersebut, kebijakan inovasi menjadi urgen, Pemerintah Daerah melalui amanat PP Nomor 38 Tahun 2017 Tentang Inovasi Daerah, telah berupaya mendorong inovasi dan modernisasi pembangunan pada tingkat provinsi, kabupaten/kota, dan desa.

Menilik Nawacita, keberhasilan visi-misi pembangunan daerah bertumpu pada kemandirian desa dalam mengembangkan potensi dan inovasi. Pembangunan desa diarahkan untuk mendukung transformasi desa sebagai motor utama pembangunan nasional yang berprinsip pada empat pilar sebagaimana dikemukakan oleh Bryant \& White, yaitu capacity, equity, empowerment, dan sustainability (Neth, Sam Ol, \& Yokohari, 2013:82). Dalam 
konteks ini, inovasi menjadi pendorong utama pembangunan ekonomi desa. Desa harus benar-benar siap menghadapi tantangan dan dinamika perubahan yang begitu cepat. Sebagai sebuah entitas dengan modal sosial yang kuat, desa berkontribusi merubah tatanan ekonomi dan iklim global, memiliki andil besar dalam mewujudkan kedaulatan pangan dan bioeconomy di masa depan (OECD, 2018: 17).

Pembangunan desa tidak lagi difokuskan pada pengelolaan tiga lingkungan desa (alam, ekonomi, dan sosial-budaya), tetapi mulai menapaki lingkungan teknologi yang kini menjadi penentu keberhasilan pembangunan desa. Berdasarkan amanat UU Nomor 6 Tahun 2014 tentang Desa dan Keputusan Menteri Desa, Pembangunan Daerah Tertinggal, dan Transmigrasi (DPDTT) Nomor 48 Tahun 2018 Tentang Program Inovasi Desa, pembangunan desa harus didasarkan pada penerapan inovasi desa menuju desa inovatif, mandiri dan berdaya saing. Persoalannya, proses menuju desa inovatif dihadapkan pada beragam hambatan substantif maupun teknis. Secara spesifik, pada level birokrasi, pragmatisme pemerintah desa sering kali mengarah pada hilangnya inovasi dan kreativitas dalam menggali sumber daya lokal di desa. Pemerintah desa belum mampu menggali sumber pendapatan baru melalui investasi produktif yang dijalankan oleh masyarakat. Dengan kata lain, pemanfaatan dana desa masih terbatas pada upaya replikasi atas proyek sebelumnya yang bias pembangunan infrastruktur.

Pemerintah desa masih menghadapi kendala praktik administratif dan cenderung melakukan tindakan kepatuhan pemerintah desa kepada hirarki di atasnya, termasuk dalam hal penggunaan dana desa yang secara umum dinilai belum tepat sasaran (Jamaluddin, Sumaryana, Rusli, \& Buchari, 2018: 17). Padahal, di sisi lain, UU Desa telah mengakui kewenangan yang dimiliki oleh pemerintah desa dalam mengatur dan mengurus kepentingan masyarakat desa berdasarkan hak asal-usul, adat istiadat, dan nilai sosial budaya secara demokratis dan partisipatif. Aspek strategis lain yang menjadi krusial dalam proses membangun desa inovatif adalah ketersediaan fasilitas fisik/nonfisik mencakup infrastruktur dan sumber daya manusia desa. Pembangunan desa inovatif pada skala lokal sangat bergantung pada kualitas dan kuantitas sarana prasarana, skill, motivasi, dan komitmen untuk mengembangkan modal sosial mencakup kepercayaan, nilai dan norma, serta jejaring sosial sesuai dengan dinamika perkembangan era (Sudirah, 2015: 150).

Inovasi desa tidak hanya sarat akan teknologi, tetapi juga strategi, pengembangan bisnis dan pemasaran, keterampilan organisasi dan manajemen (Singh \& Bhowmick, 2015: 809). Desa inovatif adalah desa yang mampu mengembangkan inovasi berbasis keunggulan lokal dan menangani permasalahan desa berbasis IPTEK (Purwanto \& Wahyuningsih, 2017: 36). Desa inovatif dipastikan mampu menjaga dampak dan keberkelanjutan inovasi, sebagaimana prinsip paling dasar sebuah inovasi, yaitu kebaruan, keberlanjutan, dan kebermanfaatan. Terdapat dua kategori model desa inovatif, yaitu top-down innovation model dan bottom-up innovation model (Suripto, 2016: 184). Literatur lain dari Darmoko menjelaskan bahwa model desa inovatif harus memiliki unsur desa inovatif, di antaranya, (a) adanya embrio inovasi; (b) adanya penguatan kelembagaan inovasi; (c) adanya penguatan jejaring dalam inovasi; (d) adanya penguatan budaya inovasi; (e) adanya perluasan IPTEK dan penyerapan isu global (Darmoko, 2015: 202-203). Secara umum, tidak semua desa inovatif memiliki model inovasi dan/atau model desa inovatif yang sama. Diferensiasi tersebut wajar terjadi akibat perbedaan kondisi demografi, geografis desa, serta geopolitik desa.

Analisis model inovasi desa dan model desa inovatif di era 4.0 dilakukan melalui telaah literatur (studi pustaka) dan studi lapangan. Riset dilakukan di Desa Panggungharjo, Kabupaten Bantul, DIY, sebuah desa inovatif yang telah memperoleh "The 4th ASEAN Rural 
Development and Poverty Eradication Leadership Award" pada bulan November 2019. Desa di Kabupaten Bantul ini, sejak awal 2014 telah bertransformasi sebagai desa promotor inovasi layanan desa berbasis digital (Sistem Informasi Desa) yang ramai dituju sebagai lokus studi banding inovasi desa. Tidak hanya modernisasi layanan publik, Desa Panggungharjo mampu memberikan lesson learned inovasi desa yang mengunggulkan elemen kelokalan desa. Kepala Desa Panggungharjo juga telah berhasil mengembangkan kapasitas politik dan kepemimpinan lokal dalam meningkatkan keberdayaan dan kemandirian desa.

Mengacu pada Utomo (2017: 14), Desa Panggungharjo telah lama menerapkan model inovasi penguatan atau reinforcement model. Dilihat dari sudut pandang model inovasi reinforcement, Desa Panggungharjo mampu; (1) mengenali/merekognisi inisiatif gagasan/perubahan; (2) mereviu progress dan mengidentifikasi kendala; (3) menentukan intervensi lanjutan yang dibutuhkan; (4) menyusun rencana tindak perubahan; (5) melakukan monitoring dan evaluasi hasil/dampak inovasi. Sayangnya, gagasan Utomo (2017) tentang reinforcement model tidak dilengkapi dengan telaah mendalam terkait intervensi, relasi aktor, dan alur inovasi.

Artikel ilmiah ini menyajikan analisis best practice model inovasi quintuple helix pada level desa. Dalam perspektif quintuple helix, inovasi desa membutuhkan akademisi dan industri untuk pertukaran dan produksi inovasi berbasis pengetahuan (Baccarne, Logghe, Schuurman, Marez, \& Shusterman, 2016: 23). Integrasi antaraktor tersebut harus diatur dengan baik oleh aktor kunci, yaitu pemerintah untuk mewujudkan sustainable rural development (CELAC, 2017: 6). Dalam ranah ini, unsur lingkungan juga menjadi helix kelima-bagian integral dari model inovasi quintuple helix. Helix tersebut merespons tuntutan sustainable development perspective (Grundel \& Dahlström, 2016: 9), pembangunan desa yang berorientasi pada socio-ecological transition (Provenzano, Arnone, \& Seminara, 2016: $\underline{443}$.

Melalui pendekatan studi kasus instrumental, artikel ilmiah ini menjawab dua pertanyaan, yaitu; (1) bagaimana best practice penerapan model inovasi quintuple helix pada konteks lokal di Desa Panggungharjo? Pertanyaan ini menjawab bagaimana peran para "helixes" dalam mewujudkan inovasi desa dan apa leverages yang menjadi penentu keberhasilan model inovasi quintuple helix merujuk pada kesuksesan inovasi di Desa Panggungharjo; (2) bagaimana konstruksi model desa inovatif mengacu pada kesuksesan Desa Panggungharjo, mencakup bagaimana tahapan pengembangan desa inovatif yang tepat sesuai konteks lokal.

\section{B. METODE PENELITIAN}

Metode penelitian yang digunakan adalah metode kualitatif dengan pendekatan studi kasus. Pemilihan studi kasus didasarkan pada tujuan yang akan dicapai oleh penulis, yang secara umum, artikel ilmiah ini ditujukan untuk mengkaji inovasi sebagai sebuah fenomena sosial yang kompleks, dan menghasilkan analisis mendalam bahkan kontribusi dalam pengembangan teori dan model inovasi. Studi kasus yang digunakan oleh penulis merupakan jenis studi kasus instrumental, sebagaimana dijelaskan oleh Stake, "the case is often looked at in depth, its contexts scrutinized, its ordinary activities detailed, and because it helps the researcher pursue the external interest" (dalam Baxter, Susan Jack, \& Jack, 2008: 549). Mengacu pada Stake dalam tulisan Baxter, Susan Jack, \& Jack (2008: 549), penulis melakukan pengamatan mendalam tentang inovasi desa di Desa Panggungharjo. Pengamatan mendalam ditujukan untuk tidak hanya menganalisis fenomena best practice model inovasi 
desa, tetapi juga mengeksplorasi aspek lain yang relevan dan memberikan kontribusi terhadap pembangunan desa, seperti elemen pendukung dan penghambat inovasi desa.

Studi kasus instrumental juga digunakan untuk memberikan wawasan tentang masalah atau untuk koreksi atas penelitian sebelumnya (Prihatsanti, Suryanto, \& Hendriani, 2018: 129). Merujuk pada pernyataan tersebut, artikel ini juga bertujuan untuk memberikan dukungan ilmiah atau koreksi/bantahan atas penelitian terdahulu tentang inovasi dan/atau model inovasi desa.

Sumber data dalam tulisan ilmiah ini adalah data primer dan sekunder (Bungin, 2013: 129), data primer terdiri dari hasil wawancara dan observasi yang dilakukan oleh penulis bersama para informan, yaitu: (1) Perwakilan Direktorat Peningkatan Sarana Prasarana, Ditjen Pembangunan Daerah Tertinggal, Kementerian Desa PDTT (1 orang); (2) Kepala Desa Panggungharjo; (3) Pengelola BUMDES (2 orang); Masyarakat Desa Panggungharjo (4 orang). Proses wawancara dilakukan dalam kurun waktu yang berbeda, tetapi berkesinambungan selama tiga bulan. Dalam prosesnya, penulis membuat daftar pertanyaan yang ditujukan kepada tiap informan sembari melakukan triangulasi sumber data melalui kroscek informasi/jawaban antarinforman. Triangulasi sumber data dilakukan untuk memastikan keaslian sumber data dan informasi (Sugiyono, 2013: 330).

Setelah pengumpulan data selesai, penulis melakukan pengolahan data melalui pemisahan data hasil penelitian lapangan; klasifikasi data hasil lapangan; analisis keterkaitan antara satuan gejala objek yang ditemui selama observasi lapangan, dan telaah teori/literatur. Hasil dari tahap ini berupa kesimpulan akhir yang meng gambarkan permasalahan penelitian. Selanjutnya, dalam proses analisis data, peneliti melakukan crosschecked untuk memastikan keabsahan dan kredibilitas data. Hasil akhir analisis data, yakni berupa draft artikel ilmiah ditinjau ulang melalui teknik validasi peer-review dengan teman sejawat untuk kebutuhan koreksi dan memperkaya analisis.

\section{KERANGKA TEORI}

\section{Inovasi dalam Perspektif Social Welfare and Development}

Secara umum, inovasi dapat diartikan sebagai sebuah hasil atau proses. Sebagai sebuah hasil, inovasi berwujud produk/kebijakan/sistem/prosedur baru atau telah mengalami penambahan nilai. Inovasi sebagai suatu proses bersifat kompleks dan tidak dapat dianggap sederhana hanya dengan menunjukkan kebaruan sebuah metode atau tahapan. Di organisasi sektor publik, inovasi menjadi substantial. Melalui inovasi, upaya peningkatan kinerja aparatur, transparansi dan akuntabilitas anggaran, serta optimalisasi public service delivery dapat lebih mudah dicapai berdasar asas efektivitas dan efisiensi. Di lain sisi, terdapat tipe/jenis inovasi (yang telah disesuaikan dengan konteks pembangunan) sebagaimana dijelaskan oleh Mulgan dan Albury (dalam Muluk, 2008: 46), di antaranya inovasi produk, inovasi proses, inovasi metode, inovasi kebijakan, dan inovasi sistem. Tiap-tiap tipe/jenis inovasi memiliki beragam dampak. Perbedaan dampak dijelaskan dalam varian level inovasi. Dalam hal ini, level inovasi mencerminkan variasi besarnya dampak yang ditimbulkan oleh inovasi yang berlangsung. Mulgan dan Albury (dalam Muluk, 2008: 46) merumuskan kategori level inovasi di antaranya inovasi inkremental, inovasi radikal dan inovasi transformatif atau sistemik.

Inovasi, pembangunan, dan kesejahteraan sosial, pada dasarnya memiliki kaitan yang sangat erat. Dinamika pembangunan dan kesejahteraan sosial berbanding lurus dengan perluasan ruang lingkup/praktik inovasi, pencarian ide-ide baru, peningkatan pemahaman dan solusi masalah sosial dan ekonomi berskala besar, juga pergeseran paradigma keilmuan 
administrasi publik, demokrasi, serta pembangunan. Pergeseran ini dipicu oleh berbagai persoalan kelembagaan seperti struktur birokrasi yang tidak efisien, kegagalan kebijakan, krisis ekonomi global yang berdampak pada masalah sosial di negara maju dan berkembang (Patel, 2015: 9). Dalam konteks pembangunan, kesejahteraan sosial dapat lebih mudah dan cepat terwujud melalui inovasi. Pada ranah ini, inovasi dapat berbentuk reformasi/perombakan struktur pemerintahan, revitalisasi fungsi birokrasi, pelibatan unsur/aktor nonpemerintahan, efisiensi anggaran, akuntabilitas anggaran, pemanfaatan IPTEKS, hingga pemberdayaan masyarakat.

\section{Pembangunan Desa dan Inovasi Desa}

Pembangunan desa merupakan proses perubahan terencana mencakup segala aspek (multi dimensi) yang terselenggara secara kolaboratif dan didasarkan pada unsur kelokalan yang dimiliki desa. Dalam hal pembangunan desa, hal mendasar yang perlu diketahui adalah bagaimana sebenarnya permasalahan yang dialami oleh desa dan seberapa besar atau kuat potensi desa yang dimiliki (Bakti, 2018: 2). Pembangunan desa yang konstruktif dan integratif akan dapat menjamin keberlanjutan desa baik yang menyangkut manusianya dan lingkungan dengan segala unsur yang ada di dalamnya (Sugeng, Rachmawati, Yosefa, Herwanto, \& Wicaksono, 2017: 116). Empat bidang prioritas dalam pembangunan desa adalah penyelenggaraan pemerintahan, pembangunan desa, pembinaan kemasyarakatan, dan pemberdayaan masyarakat (Alam \& Mamu, 2016: 96). Sama halnya dengan proses pembangunan pada umumnya, pembangunan desa bertumpu pada penerapan nilai-nilai dasar governance dan keberlanjutan sebagai aspek principal. Faktanya, keterbatasan pengetahuan, keterampilan dan sumber daya desa acapkali menghambat kemajuan pembangunan desa.

Pembangunan desa merupakan proses perubahan terencana mencakup segala aspek (multi dimensi) yang terselenggara secara kolaboratif dan didasarkan pada unsur kelokalan yang dimiliki desa. Proses dan intervensi menjadi dua hal mendasar dalam pembangungan desa. Artinya, pembangunan desa mencakup proses pemberdayaan masyarakat dalam pengelolaan sumber daya desa melalui intervensi dalam bentuk asistensi, edukasi dan pengembangan literasi masyarakat desa. Intervensi dimaksudkan untuk memfasilitasi sebuah proses perubahan sosial dan pemerataan kesejahteraan bagi masyarakat desa yang tidak terlepas dari campur tangan pemerintah sebagai pemilik berbagai sumber daya (Purnamasari, 2018).

Mengubah prinsip pertumbuhan semata menjadi prinsip pemerataan (equity), pertumbuhan (eficiency) dan keberlanjutan (sustainability) menjadi sangat penting bagi pembangunan desa masa kini (Suharyanto \& Sofianto, 2012: 257). Transformasi pembangunan desa dan masyarakat yang berkelanjutan mensyaratkan new challenge-driven innovations (Grundel \& Dahlström, 2016: 964). Dalam perkembangaannya, di tengah industrialisasi 4.0., pembangunan desa diarahkan pada upaya peningkatan kesejahteraan desa melalui program desa inovatif. Dalam ranah konseptual dan empiris, desa inovatif dapat dimaknai sebagai desa yang mampu memetakan arah dan mencapai tujuan pembangunan desa melalui pola kerja kolaboratif antaraktor/lintas sektor pembangunan melalui pengembangan inovasi, baik berupa proses maupun hasil. Dalam rangka mewujudkan desa inovatif, program/kebijakan nasional bertajuk "Program Inovasi Desa" (PID) yang diselenggarakan oleh Kementerian Desa dan Pembangunan Daerah Tertinggal dan Transmigrasi (Kemendesa PDTT). PID didukung oleh pendanaan dari Bank Dunia melalui restrukturisasi program yang sebelumnya difokuskan pada pendampingan desa dalam pelaksanaan Undang-Undang Desa. Sesuai dasar hukum tersebut, tujuan terbentuknya desa inovatif adalah untuk memastikan kontinuitas peningkatan kapasitas dan budaya inovasi. 
Penelitian terdahulu yang juga menegaskan urgensi inovasi dalam membangun desa di Indonesia adalah artikel ilmiah berjudul "Pengembangan Model Smart Rural Untuk Pembangunan Kawasan Perdesaan di Indonesia" (Andari \& Ella, 2019). Dalam artikel tersebut diungkapkan bahwa inovasi menjadi salah satu prinsip dasar pembangunan smart village atau smart rural, yang dalam implementasi kebijakan/program desa cerdas tersebut, peningkatan penggunaan research \& development, inovasi, pengetahuan, dan pembelajaran menjadi faktor utama penentu kemajuan desa (Andari \& Ella, 2019: 47). Penelitian lain yang lebih spesifik mengulas indikator desa inovatif adalah artikel ilmiah "Potensi Desa Inovasi di Kabupaten Pemalang" (Darmoko, 2015: 202-203). Dijelaskan bahwa terdapat lima unsur yang melekat pada desa inovatif, yaitu (a) embrio inovasi; (b) penguatan kelembagaan inovasi; (c) penguatan jejaring inovasi; (d) penguatan budaya inovasi; (e) perluasan IPTEK dan penyerapan isu global (Darmoko, 2015: 202-203). Lebih detail, peneliti juga menggunakan kelima prinsip tersebut sebagai perspektif analisis. Tidak hanya di Indonesia, inovasi desa juga menjadi strategi rural development di beberapa negara lain. Finlandia mengusung inovasi sosial sebagai solusi dalam mengatasi persoalan pembangunan di remote areas. Sebagai salah satu negara dengan indeks kebahagiaan tertinggi, Finlandia berhasil membangun budaya inovasi melalui pemberdayaan masyarakat organisasi lokal (Rantamäki and Kattilakoski dalam (Madureira \& Torre, 2019: 6)

\section{Dinamika Model Inovasi Linier Hingga Helix}

Di era 90-an, tepatnya tahun 1993, 1995, Leydesdorff \& Etzkowitz (1998) memperkenalkan kepada publik tentang konsep helix yang dalam waktu singkat telah dikenal secara luas di negara-negara maju (Jaelani, 2019: 122). Konsep helix ini juga dikenal sebagai sebuah metode pengembangan kebijakan yang berbasiskan pada inovasi (Sofhani \& Nurrahma, 2017: 18).

Konsep helix didasarkan dalam gagasan bahwa inovasi merupakan hasil interaktif yang melibatkan berbagai jenis aktor. Masing-masing aktor berkontribusi sesuai fungsi kelembagaannya di masyarakat. Universitas, industri, pemerintah termasuk dalam triple helix. Masyarakat sipil dan masyarakat berbasis media dan budaya masuk dalam quadruple helix. Konsep ini semakin meluas dengan adanya quintuple helix yaitu penambahan aktor masyarakat dari lingkungan alami (Praswati, 2017).

Triple helix innovation model bertumpu pada tiga pilar inovasi, yaitu pemerintah, industri dan akademisi (universitas) (Widjajani, Fajarwati, Hidayat, \& Haryadi, 2018: 141). Masing-masing pilar memiliki peran yang saling melengkapi. Pemerintah menjalankan peran dan fungsinya sebagai policy maker, pihak yang memiliki wewenang dan kuasa dalam perumusan kebijakan, pengaturan (hukum), dan sumber daya finansial. Industri berperan sebagai penyedia kebutuhan, pemilik mesin produksi inovasi, teknologi, skilled labor, juga sumber daya finansial. Terakhir, akademisi, dalam hal ini universitas, disebut juga sebagai innovator propublik (Sulaksono, 2018: 370), berperan sebagai pusat pengembangan ilmu pengetahuan dan informasi berbasis riset. Ketiga helixes bekerja sama untuk menciptakan inovasi yang dapat meningkatkan derajat kemajuan sebuah negara.

Salah satu best practice dari model inovasi triple helix di era 90-an adalah pengembangan sentra information and technology (IT) di Silicon Valley, California, Amerika Serikat (Pique, Berbegal-Mirabent, \& Etzkowitz, 2018). Koordinasi antar masingmasing pilar/helix dilakukan dengan sangat baik. Helix pemerintah menyediakan tanah, kemudahan skema pembiayaan, kebijakan bebas pajak yang fleksibel dan pedoman yang sesuai kebutuhan pengembangan teknologi informasi di California, AS. Helix industri menjadi penghasil inovasi teknologi kelas dunia, seperti Apple, Google, Yahoo, Intel, 
Microsoft. Stanford University sebagai helix universitas berperan dalam research and development. Telah sejak lama, Silicon Valley diakui sebagai dunia kerja yang dikembangkan oleh para profesor di Stanford University.

Terlepas dari kesuksesan triple helix di Silicon Valley, kritik atas model inovasi triple helix terus bermunculan. Sebagai sebuah model yang menekankan pada integrasi tiga aktor, pemerintah, industri/bisnis/swasta, dan akademisi/universitas, seharusnya juga mengacu pada the shifting paradigm "from government to governance". Quadruple helix menyempurnakan triple helix dengan memperkenalkan helix keempat, pihak yang sebenarnya menjadi bagian penting dari tata kelola inovasi, yaitu civil society. Dalam perkembangan quintuple helix, terdapat beberapa rujukan yang menyebutkan perbedaan penamaan/aktor dari helix keempat. Perbedaan pemahaman para ahli terkait figur helix keempat telah dirangkum oleh peneliti (tabel 1). Adapun terlepas dari perbedaan tersebut, artikel ini menyepakati bahwa helix keempat dapat disebut sebagai masyarakat berbasis media dan budaya (Carayannis, E. G., Barth, T. D., \& Campbell, 2012).

Tabel 1.

Diferensiasi Definisi Helix Keempat dalam Quadruple dan Quintuple Helix

Referensi

(Yawson, 2012)

(Carayannis, E. G.,

Barth, T. D., \&

Campbell, 2012)

(European

Commission, 2012)

(Baber, 2001)

(Mehta, 2003)

(Delman J.and

Madsen S. T., 2007)

(Caduff C., 2010)

\section{Definisi Helix Keempat}

User atau pengguna inovasi dari sebuah perusahaan maupun institusi pemerintahan. Dalam konteks ini, inovasi didorong oleh kebutuhan pengguna

Publik dan masyarakat sipil yang berbasis media dan berbasis budaya. Termasuk di dalamnya: budaya dan budaya inovasi; nilai-nilai dan gaya hidup; multikulturalisme dan kreativitas; media; universitas seni dan seni; dan sistem inovasi bertingkat (lokal, nasional, dan global).

Masyarakat sipil sebagai pengguna inovasi (komunitas masyarakat seperti LSM, asosiasi konsumen, dll.)

Pakar ilmiah eksternal yang memberi masukan/rekomendasi kepada pemerintah (contoh kasus di Singapura pada awal 1980an tentang sains dan kebijakan industri)

Aktor dan individu dengan afiliasi tertentu membentuk "komunitas atau asosiasi bidang ilmu (misalnya bidang bioteknologi, nanoteknologi, dll.)

Organisasi nirlaba independen berbasis anggota yang menggabungkan pendanaan dari pemerintah dan sektor swasta

Penelitian seni dan seni itu sendiri, sebagai bentuk baru penciptaan dan mungkin juga sebagai bentuk baru penciptaan pengetahuan

Sumber: hasil telaah peneliti merujuk pada (Praswati, 2017)

Lebih kompleks dari triple helix dan quadruple helix, pendekatan inovasi quintuple helix yang dipelopori oleh Carayannis \& Campbell telah membawa khasanah baru tentang model inovasi berbasis helix. Quintuple helix melengkapi quadruple helix dengan menambahkan helix kelima, yaitu lingkungan alami. Helix terakhir ini memiliki modal alam sebagai pemacu inovasi. Selain pemerintah, industri, perguruan tinggi, dan masyarakat sipil, lingkungan alami memiliki peran penting dalam proses produksi inovasi dan pengetahuan untuk mewujudkan pembangunan berkelanjutan. Dalam perspektif Carayannis et al. (2012), 
quintuple helix selanjutnya menguraikan arti pembangunan berkelanjutan bagi inovasi dengan memunculkan konsep eco-innovation dan eco-entrepreneurship. Bagi model helix, lingkungan alami berkontribusi dalam menjaga keseimbangan antar helix dan memastikan keberlanjutan inovasi. Quintuple helix mendorong perbaikan pada struktur pengetahuan dan inovasi; menekankan transisi sosioekologis yang diperlukan masyarakat dan sektor ekonomi di abad ke-21. Oleh karena itu, quintuple helix dapat dikatakan sangat sensitif secara ekologis (Praswati, 2017: 699).

\section{HASIL DAN PEMBAHASAN}

\section{Analisis Model Inovasi Quintuple Helix di Desa Panggungharjo}

Urgensi penerapan model quintuple helix pada ranah inovasi desa adalah perwujudan dari pembangunan desa berbasis pengetahuan (Kolehmainen et al., 2016: 5). Pada era sekarang, knowledge-based development harus dipraktikkan pada seluruh level pemerintahan, termasuk desa. Quintuple helix memungkinkan kemajuan desa melalui integrasi sektor pendidikan, ekonomi, politik, dan pemberdayaan masyarakat (Carayannis \& Grigoroudis, 2016: 37). Model ini juga memungkinkan pengelolaan industri pada tingkat desa seperti BUMDes untuk memiliki daya saing, kreatifitas dan kapabilitas (Sukarno, 2018: 4). Implementasi model inovasi berbasis quintuple helix di Desa Panggungharjo mengalami banyak penyesuaian. Tidak ada lagi batasan yang jelas tentang pembagian fungsi/peran masing-masing helix. Dalam praktik inovasi di Desa Panggungharjo, helix pertama, pemerintah desa justru memainkan fungsi perguruan tinggi sebagai dalam pengelolaan dan riset R-UCO (bekerja sama dengan helix kedua, industri). Dilihat dari perspektif kapasitas politik dan kepemimpinan, serta kapasitas proses dan birokrasi, helix pertama mampu menggunakan political capital dengan sangat baik. Di Desa Panggungharjo, pemerintah desa telah menghilangkan peran eksklusif perguruan tinggi sebagai penghasil pengetahuan. Praktik ini menyiratkan bahwa formula quintuple helix mengalami penyesuaian dengan konteks lokus.

Sebagaimana dijelaskan oleh Gibbons, et.al pada tahun 1994, penciptaan pengetahuan dan teknologi oleh akademisi/perguruan tinggi dapat dilakukan melalui dua cara. Pertama, mengacu pada sistem produksi pengetahuan melalui penelitian dasar mengenai ilmu atau pengetahuan murni yang terstruktur dalam logika disiplin dan tidak berfokus pada penerapan pengetahuan. Kedua, mengacu pada sistem produksi pengetahuan berdasarkan prinsip sains (diterapkan) dan teknologi (ditransfer) (Praswati, 2017: 691). Cara kedua menunjukkan adanya diversifikasi lokasi potensial dimana pengetahuan dapat diciptakan. Tidak lagi hanya perguruan tinggi, tetapi lembaga nonperguruan tinggi, seperti lembaga/pusat penelitian, lembaga pemerintah, laboratorium industri, konsultan saling berinteraksi yang menghubungkan keseluruhan informasi melalui elektronik, organisasional, sosial, formal dan informal melalui fungsi jaringan komunikasi (Gibbons et.al., 1994 dalam Praswati, 2017: 692). Maka tidak mengherankan jika pada triple helix terdapat fungsi yang saling beririsan antara helixes, khususnya pada aspek research and development yang dilakukan oleh pemerintah, industri dan perguruan tinggi.

Menilik dominasi peran helix pemerintah dalam proses produksi pengetahuan dan inovasi di Desa Panggungharjo, pernyataan Gibbons, et.al (1994) tentang variasi knowledge development menjadi sangat relevan. Pengetahuan dan teknologi atas inovasi pengolahan minyak jelantah (R-UCO) di Desa Panggungharjo bersumber dari kerja sama Pemerintah Desa Panggungharjo dengan industri, PT Tirta Investama, Danone, Aqua. Penandatanganan MoU dilakukan oleh kedua belah pihak untuk terus meningkatkan kualitas dan kuantitas 
produksi R-UCO, serta pemetaan rantai distribusi dan pemasaran produk. Hal ini menjadi sangat menarik karena di saat yang sama, pemerintah desa tidak hanya menggunakan political capital, namun juga economic capital (milik helix industri), human capital (milik helix akademisi/perguruan tinggi), bahkan natural capital (milik helix lingkungan alami). Peneliti menemukan fakta lain yang juga menarik tentang hal tersebut, berdasarkan hasil wawancara, kepala desa mengungkapkan bahwa pengetahuan pengolahan R-UCO bermula dari ide yang didukung oleh latar belakang pendidikan beliau di bidang farmasi Universitas Gadjah Mada. Informasi ini sekaligus menunjukkan kapasitas kepemimpinan yang tidak hanya andal dalam aspek manajerial, tetapi juga kognitif bahkan aspek teknis.

Selain pemerintah desa, peneliti mengidentifikasi state actor lain yang juga menjalankan peran helix pemerintah, diantaranya BPKP (Badan Pengawas Keuangan dan Pembangunan) dan Kantor Arsip Kabupaten Bantul. Kedua organisasi milik pemerintah tersebut diperuntukkan untuk membantu Desa Panggungharjo mewujudkan akuntabilitas dan transparansi di bidang keuangan, pemerintahan, dan pembangunan. Sebagai payung hukum kerja sama, Pemerintah Desa Panggungharjo telah menandatangani MoU dengan keduanya pada tahun 2014 (Pemerintah Desa Panggungharjo, 2018).

Helix kedua, industri yang diwakilkan oleh PT Tirta Investama, Danone, Aqua menjalankan peran sebagai mitra usaha pengolahan R-UCO. Menariknya, sebagai desa dengan APBDes 2019 sebesar 4,5 Milyar, industri dari luar desa tidak perlu banyak berperan untuk mendorong perekonomian desa. Sejak 2012, dengan memanfaatkan alokasi dana desa dan sumber dana lainnya, Desa Panggungharjo telah mampu mandiri secara ekonomi. Terlebih lagi, pada bulan Maret 2013, BUMDes Panggung Lestari telah resmi dibentuk sebagai lumbung ekonomi desa. Semenjak pendirian BUMDes, helix industri di Desa Panggungharjo terbilang unik. Terdapat dua jenis industri yang memiliki orientasi dan bussiness process yang berbeda. PT. Tirta Investama, sebagai industri multi-national company menjalankan praktik entrepreneurship yang murni berorientasi pada profit, sedangkan BUMDes Panggung Lestari, sebuah village-owned enterprise menjalankan praktik entrepreneurship yang berorientasi pada profit dan sosial atau social entrepreneurship (socio-preneurship).

Peneliti menetapkan kategori BUMDes sebagai helix industri karena pada dasarnya, status BUMDes adalah badan usaha yang berorientasi pada pembangunan ekonomi desa. Pada tahun 2016, BUMDes Panggung Lestari juga telah membentuk perseroan terbatas PT Sinergi Panggung Lestari sebagai perusahaan yang fokus mengelola R-UCO dan tamanu oil. BUMDes Panggung Lestari memiliki economic capital yang dimanfaatkan hasilnya untuk kepentingan publik. Sama halnya dengan BUMN, BUMDes juga menjalankan fungsi pemerintahan, artinya, meskipun pengelolaan BUMDes Panggung Lestari dilakukan secara profesional, sebagain besar keuntungan BUMDes dimanfaatkan untuk pembangunan desa. Keunikan BUMDes sebagai helix industri dapat pula dilihat dari nilai kerakyatan yang diusung BUMDes. Unsur sosial yang melekat pada BUMDes menunjukkan bahwa terdapat pula peran helix keempat, civil society dalam pengelolaan BUMDes. Peneliti berpendapat bahwa secara fisik, BUMDes adalah helix industri, namun secara non-fisik BUMDes justru dapat dikatakan sebagai wujud aktualiasi semua helix organik di dalam quintuple helix.

Eksistensi helix ketiga, akademisi atau perguruan tinggi di Desa Panggungharjo ditunjukkan oleh terlaksananya beberapa jalinan kerja sama antara pemerintah desa dengan beberapa institusi pendidikan tinggi. Fakultas Teknik Universitas Janabadra Yogyakarta yang telah bersinergi dengan Desa Panggungharjo dalam mengembangkan teknologi tepat guna pengelolaan sampah untuk energi. Pada tahun 2017, kerja sama tersebut diresmikan melalui penandatanganan MoU oleh kedua belah pihak. Fakultas Teknik Universitas 
Janabadra juga menjadikan Desa Panggungharjo sebagai laboratorium lapangan bagi mahasiswa, khususnya jurusan Teknik Mesin dan Teknik Sipil. Kedua helix ini juga menyepakati pelaksanaan dharma pendidikan tinggi bidang pendidikan melalui kuliah umum, bidang penelitian dan pengabdian kepada masyarakat melalui pengembangan teknologi tepat guna (Pemerintah Desa Panggungharjo, 2018).

Hubungan kerja sama dengan helix akademisi juga dijalin dengan Politeknik Kesehatan Kemenkes Yogyakarta pada tahun 2019 melalui peresmian Desa Panggungharjo (Puskesmas Sewon 2) sebagai wilayah binaan Program Inter-Professional Education (IPE) dan Inter-Professional Collaboration (IPC) (Pemerintah Desa Panggungharjo, 2019). Sebagai penghasil pengetahuan, Politeknik Kesehatan Kemenkes Yogyakarta mengambil peran dalam pemberdayaan kesehatan di Desa Panggungharjo, salah satunya dengan mengirimkan mahasiswa praktik lapangan, melakukan sinergi penelitian dan pelaksanaan pengabdian kepada masyarakat di Desa Panggungharjo. Lebih lanjut, penguatan peran perguruan tinggi dalam pemberdayaan BUMDes ditunjukkan dengan pembentukan Rembug Akademisi BUMDes yang menghasilkan "Pakta Kerja Sama Akademisi BUMDes", komitmen dan action plan pendampingan BUMDes.

Helix keempat merupakan helix organik terakhir. Pada umumnya, helix ini dikenal dengan civil society yang juga menjadi aktor kunci dalam good governance. Helix keempat dalam artikel ilmiah ini dimaknai sebagai masyarakat berbasis media dan berbasis budaya, mengintegrasikan dan menggabungkan dua bentuk capital, yaitu social capital dan information capital. Modal sosial diwujudkan dalam bentuk tradisi, norma, nilai, dll, sedangkan modal informasi dapat berupa televisi, internet, surat kabar, website, dll. (Praswati, 2017: 698). Di Desa Panggungharjo, modal sosial memiliki tiga komponen utama, yaitu norma (norm), kepercayaan (trust), dan jaringan (networking) (analisis jaringan (kerja sama) dijelaskan dalam bahasan kapasistas politik dan kepemimpinan).

Norma, baik tertulis maupun tidak telah mengatur pola hidup masyarakat Desa Panggungharjo. Sejak 2013, masyarakat secara sadar mengumpulkan sampah plastik untuk disetorkan ke bank sampah. Minyak jelantah juga tidak lagi dibuang dan dijual ke BUMDes untuk diolah. Norma tertulis tentang pengolahan sampah ini tertuang dalam Peraturan Desa Nomor 7 Tahun 2016 tentang Pengelolaan Sampah dan Pedoman Pendirian Bank Sampah. Adapun norma tidak tertulis dipengaruhi oleh adanya kepercayaan vertical (pemerintah desa) dan horizontal (sesama masyarakat desa). Sebagai bentuk kepercayaan masyarakat, Kepala Desa telah dipilih untuk memimpin Desa Panggungharjo untuk kedua kalinya. Keberhasilan BUMDes di tingkat internasional dan predikat Desa Terbaik Nasional tahun 2014 juga ditentukan oleh tingkat kepercayaan masyarakat terhadap Kepala Desa, jajaran pemerintah desa dan antarmasyarakat desa. Berbekal percaya, masyarakat memiliki kesadaran sosial untuk menaati peraturan (norma) sehingga pengelolaan BUMDes khususnya R-UCO mendapatkan banyak apresiasi. Modal sosial juga menjadi faktor penentu dalam pelestarian unsur budaya di Desa Panggungharjo. Sebuah objek wisata sejarah dan budaya, Kampung Mataraman telah dikembangkan pada tahun 2017. Sejak saat itu, Kampung Mataraman ramai dikunjungi wisatawan yang tertarik menikmati salah satu ikon inovasi Desa Panggungharjo.

Modal informasi yang melekat pada helix keempat (khususnya unsur media dari masyarakat berbasis media dan budaya) tidak berasal dari masyarakat. Di Desa Panggungharjo, website desa yang dikelola dengan sangat baik, informatif, dan selalu up-todate merupakan hasil inovasi berbasis modal informasi yang diproduksi oleh helix pemerintah. Masyarakat tidak berperan sebagai penghasil modal informasi, dengan kata lain, masyarakat hanya berperan sebagai pengguna, bukan penghasil pengetahuan dan inovasi 
berbasis teknologi dan pengetahuan. Uniknya, pengguna inovasi ini tidak hanya masyarakat desa, publik secara umum juga dapat merasakan manfaat website sebagai media informasi dan akuntabilitas pengelolaan anggaran desa.

Helix keempat juga dapat didefinisikan sebagai organisasi nirlaba independen berbasis anggota yang menggabungkan pendanaan dari pemerintah dan sektor swasta. Masyarakat dalam proses inovasi dapat berperan sebagai pemilik dan pengguna pengetahuan. Rumah Zakat telah menjalin kerja sama dengan lembaga Badan Pelaksana Jaring Pengaman Sosial (Bapel JPS) Desa Panggungharjo sejak 2017. Rumah Zakat, sebagai organisasi nirlaba membantu Desa Panggungharjo melalui program peningkatan kualitas dan layanan kesehatan masyarakat melalui fasilitas ambulans gratis dan program pemberdayaan kesehatan Inter Professional Education (IPE) dan Inter Professional Collaboration (IPC) bersama Politeknik Kesehatan Kemenkes Yogyakarta.

Helix kelima dalam quintuple helix model adalah lingkungan alami (modal alam) sebagai sarana untuk mewujudkan pembangunan berkelanjutan, bahkan katalisator inovasi. Jauh sebelum UNDP mengenalkan konsep sustainable development, desa di Indonesia bergantung pada lingkungan alami. Pada dasarnya terdapat tiga unsur lingkungan yang melekat pada desa sebelum munculnya era digitalisasi, yaitu lingkungan alam/i, lingkungan ekonomi, dan lingkungan sosial-budaya. Karenanya, peneliti berpendapat bahwa identifikasi helix lingkungan alami sebagai helix terakhir dalam model quintuple helix justru mencerminkan "kelalaian" pelaku inovasi dalam menempatkan alam sebagai penopang keberlanjutan inovasi. Lingkungan alami dalam konteks quintuple helix berperan sebagai helix nonorganik, artinya, lingkungan alami bukan sebuah subjek, tetapi menjadi dasar dari helix pemerintah, industri, dan masyarakat dalam bertindak. Di Desa Panggungharjo, modal alami digunakan sebagai cara hidup. Di BUMDes Panggung Lestari, wawasan lingkungan hidup menentukan produksi inovasi dan pengetahuan sehingga dapat memajukan ekonomi desa. Hal ini dapat dibuktikan dari inovasi KUPAS dan pengolahan sampah R-UCO. Secara umum, Desa Panggungharjo mampu mengelola inovasi berbasis kolaborasi dengan sangat baik dalam berbagai aspek. Sebagaimana dijelaskan oleh García-terán \& Skoglund (2019: 1275), quintuple helix efektif menjelaskan hubungan antara aspek politik, ekonomi, sosial, dan science. Gambar 1. memberikan gambaran model inovasi quintuple helix, input-output inovasi, dan alur inovasi di Desa Panggungharjo. 


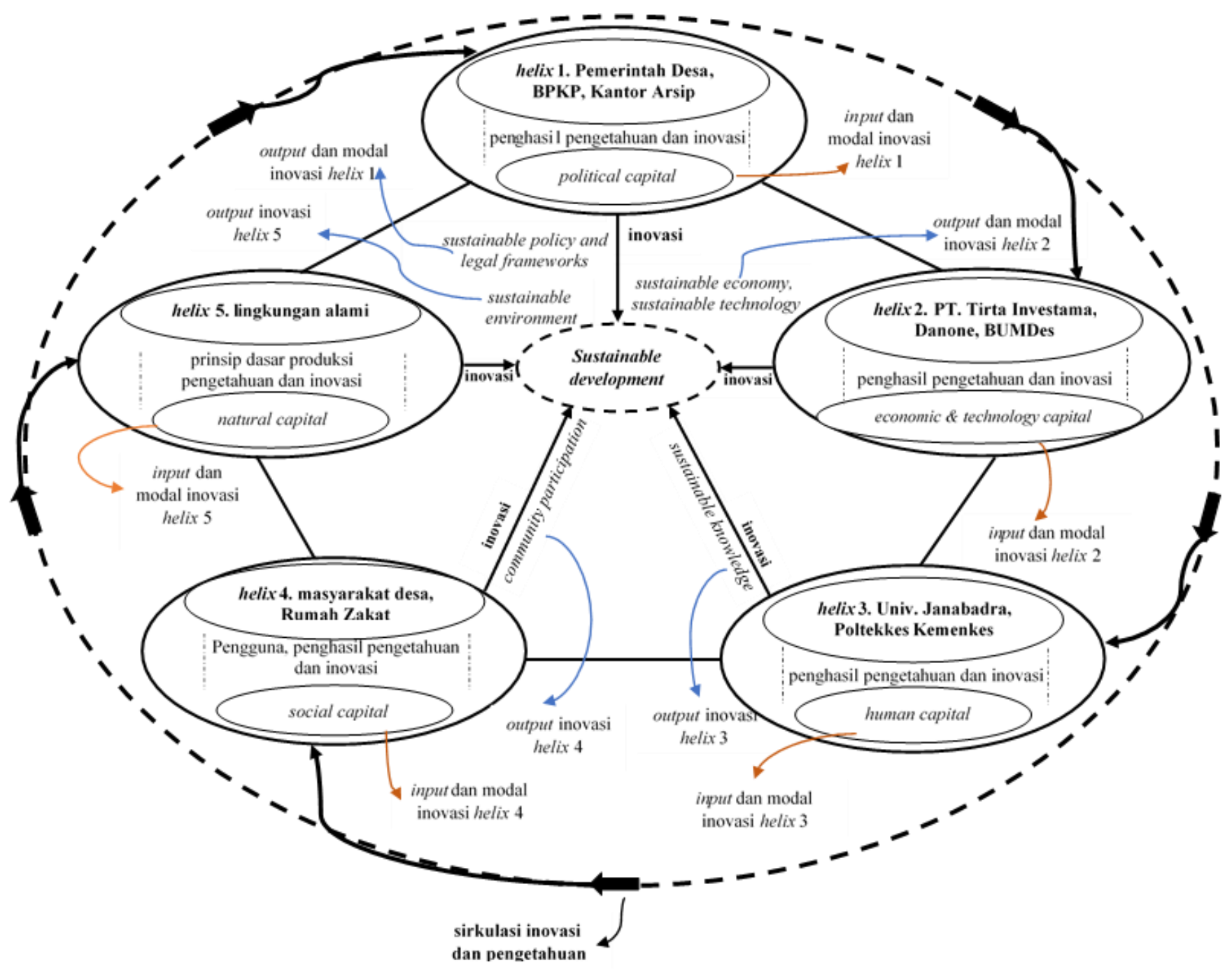

Gambar 1.

Model Inovasi Quintuple Helix di Desa Panggungharjo (Sumber: modifikasi model quintuple helix Carayannis \& Campbell (2012: 7)

Tiga Kapasitas Utama (Leverage) Pendorong Keberhasilan Praktik Model Inovasi Quintuple Helix di Desa Panggungharjo

Peran pemerintah desa sangat dominan dalam proses inisiasi dan eksekusi inovasi. Bahkan, figur kepala desa dengan literasi yang tinggi mampu memimpin birokrasi dan inovasi dengan sangat baik. Jelas bahwa kepala desa memiliki peran sentral dalam penciptaan dan pengembangan inovasi. Dalam mewujudkan visi Desa Panggungharjo, kepala desa dinilai mampu menciptakan inovasi desa berkelanjutan dan menghadirkan kemandirian desa dengan bertumpu pada tiga kapasitas utama, yaitu kapasitas politik dan kepemimpinan; kapasitas proses dan birokrasi; dan kapasitas sosial (gambar 2). 


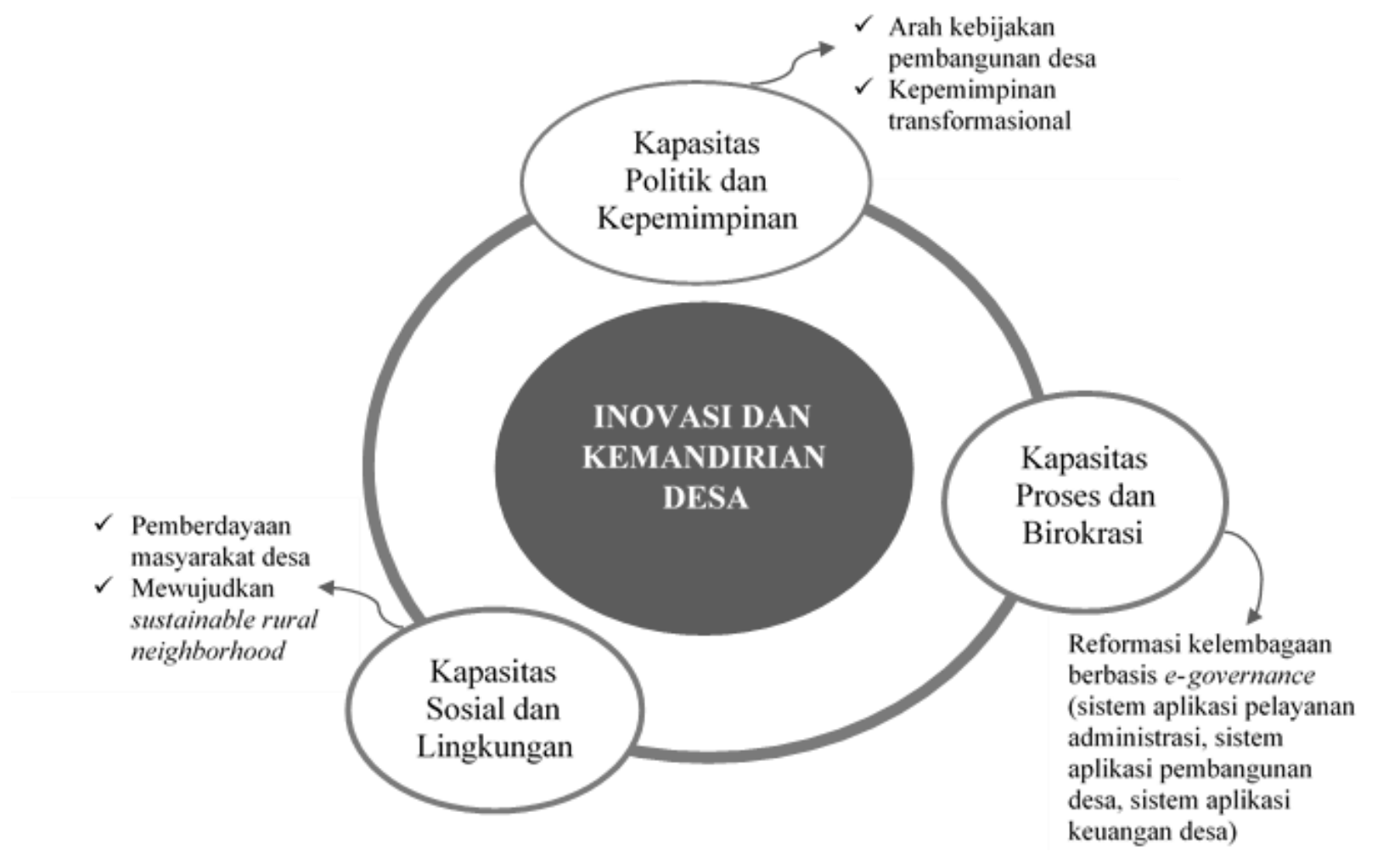

Gambar 2.

Tiga Kapasitas Utama Dasar Inovasi dan Kemandirian Desa (Sumber: modifikasi Hadi

$\underline{(2019: 6)}$

\section{Kapasitas Politik dan Kepemimpinan}

November 2019, sebelum pandemi Covid-19 mengunci berbagai lini dan aktivitas masyarakat, kepala desa Panggungharjo menerima penghargaan "The 4th ASEAN Rural Development and Poverty Eradication Leadership Award" di Nay Pyi Taw, Myanmar, pada tanggal 8 November 2019 pada ajang ASEAN Leadership Award, sebuah ajang penghargaan bagi ASEAN bagi Civil Society Organization (CSO) dan Private Sector (swasta). Desa Panggungharjo didaulat menjadi desa terbaik atas kesuksesan Badan Usaha Milik Desa (BUMDes) Panggung Lestari dalam memajukan sustainable rural neighborhood. Keberhasilan ini bukan kali pertama bagi Desa Panggungharjo, banyak apresiasi yang ditujukan bagi BUMDes Panggung Lestari yang telah berhasil berkontribusi bagi pembangunan perdesaan dan pengentasan kemiskinan. Produk-produk BUMDes seperti (1) Jasa Pengolahan Sampah (KUPAS) atau sustainable solid waste management; (2) R-UCO (Refined Used Cooking Oils), pengolahan limbah minyak jelantah atau sustainable liquid waste management; (3) AGRO, pertanian berkelanjutan (sustainable farming); (4) SWADESA atau Swalayan Desa, wadah layanan pemasaran produk-produk lokal desa; dan beberapa produk lain seperti wisata edukasi Kampung Mataraman dan pengolahan tamanu oil menjadi bukti keberhasilan inovasi yang digerakkan oleh kapasitas politik dan kepemimpinan desa.

Sebagai pemimpin desa, Kepala Desa Panggungharjo mampu menggunakan sumber kekuasaan politis dengan baik. Hal tersebut dapat dilihat dari political will kepala desa dalam membangun ketahanan ekonomi desa melalui BUMDes. Kapasitas politik dan kepemimpinan kepala desa dalam menentukan arah kebijakan dan pembangunan desa diwujudkan dalam penerbitan puluhan produk hukum berupa Peraturan Desa (Perdes) sejak 
tahun 2012 sebagai arah dan dasar kebijakan, beberapa di antaranya, (1) Peraturan Desa Nomor 9 Tahun 2015 Tentang Badan Usaha Milik Desa; (3) Peraturan Desa Nomor 7 Tahun 2016 Tentang Pengelolaan Sampah dan Pedoman Pendirian Bank Sampah; (3) Peraturan Desa Nomor 6 Tahun 2019 Tentang Rencana Pembangunan Jangka Menengah Desa Tahun 2019-2024; dll.

Selain itu, berdasar pada otoritas yang telah tertuang dalam Peraturan Desa, kepala desa bersama pimpinan BUMDes, pada pertengahan tahun 2017, berhasil menjalin kerja sama pengembangan R-UCO dengan PT Tirta Investama, Danone Aqua, Klaten, Jawa Tengah; kerja sama dalam sektor pemerintahan dan keuangan dengan BPKP; dan kerja sama pengelolaan naskah dinas dengan Kantor Arsip Kabupaten Bantul. Berbekal kapasitas politik dan kepemimpinan yang sangat mumpuni, Kepala Desa Panggungharjo juga telah membentuk lembaga desa lain guna mengatasi berbagai persoalan di Desa Panggungharjo, Badan Pelaksana Jaring Pengaman Sosial (Bapel JPS), Lembaga Mediasi Desa (LMD), Lembaga Pengelola Sistem Informasi Desa, dan sejumlah lembaga desa lainnya.

\section{Kapasitas Proses dan Birokrasi}

Kapasitas proses dan birokrasi mencakup kemampuan Desa Panggungharjo dalam melaksanakan pelayanan, mewujudkan reformasi kelembagaan/birokrasi, dan pengembangan kompetensi sumber daya manusia aparatur (SDMA). Kapasitas ini wajib dimiliki oleh kepala desa dan pemerintah desa. Merujuk pada pemerintah desa menjadi sentrum governance desa dimana kedudukan kepala desa adalah sebagai personifikasi pemerintah desa. Pemerintah desa dan kepala desa merupakan bagian dari mata rantai birokrasi negara yang menjalankan fungsi regulasi dan kontrol melalui pelayanan administratif, implementasi pembangunan, dan pemberdayaan masyarakat (Sidik, 2015).

Dilihat dari perspektif kelembagaan, keberhasilan Desa Panggungharjo menjadi desa inovatif di era 4.0 sangat ditentukan oleh kemampuan birokrasi desa dalam menerapkan $e$ governance atau tata kelola pemerintahan berbasis teknologi. Sejak tahun 2012, Desa Panggungharjo telah merintis website desa dan berhasil melakukan "praktik 4.0" sejak awal 2015 melalui pengembangan $e$-service, sebuah inovasi pelayanan publik desa terpadu yang mencakup pelayanan administrasi publik, pengelolaan barang dan jasa publik, dan manajemen keuangan publik berbasis elektronik. Secara umum, optimalisasi e-service Desa Panggungharjo dapat dilihat dari website Desa Panggungharjo yang kaya akan informasi. Layanan informasi dalam website bersifat umum dan khusus. Informasi umum seputar profil desa, sejarah, berita, dan berbagai produk layanan. Sedangkan informasi khusus mencakup progress report atau hasil pembangunan desa, seperti Laporan Realisasi Dana Desa, Laporan Realisasi APBDes, hingga daftar Peraturan Desa, dan ragam dokumen lainnya telah terlampir secara lengkap dan mudah diakses. Tidak hanya website, pengembangan Sistem Informasi Desa (SID) di Desa Panggungharjo menjadi kunci keberhasilan reformasi birokrasi pada tingkat desa. Melalui SID, Desa Panggungharjo berhasil mengembangkan Sistem Aplikasi Pelayanan Administrasi, Sistem Aplikasi Pembangunan Desa, dan Sistem Aplikasi Keuangan Desa.

Selanjutnya, ditinjau dari perspektif pengembangan kompetensi SDMA, terhitung sejak 2015, Kepala Desa Panggungharjo telah menugaskan beberapa aparatur desa untuk meningkatkan kualitas dan kualifikasi dengan menempuh pendidikan tinggi di Sekolah Tinggi Pembangunan Masyarakat Desa "APMD”, Yogyakarta. Tidak hanya itu, dengan membuka akses studi banding, aparatur desa dapat terus terlatih melalui rutinitas knowledge sharing. Terobosan inovasi secara kontinyu juga turut menjadi trigger bagi aparatur desa dalam meningkatkan kompetensi dan literasi. Hingga tahun 2020, inovasi Desa 
Panggungharjo telah merambah di semua lini kehidupan. Dengan demikian, aparatur desa memiliki banyak ruang untuk menunjukkan kontribusinya kepada khalayak desa.

\section{Kapasitas Sosial dan Lingkungan}

Interaksi antara helix pemerintah desa, BUMDes, dan masyarakat. membentuk kapasitas sosial dan lingkungan di Desa Panggungharjo. Dari perspektif pemerintah desa dan BUMDes, kapasitas sosial dan lingkungan dapat dilihat dari kemampuan kedua helix tersebut dalam mengelola program pemberdayaan masyarakat bidang ekonomi, sosial, kesehatan, pendidikan, bahkan lingkungan hidup. Secara informal, sosial BUMDes sebagai wadah interaksi dan edukasi masyarakat. Sedangkan dari perspektif masyarakat, kapasitas sosial dan lingkungan diwujudkan dalam bentuk peningkatan partisipasi masyarakat. Setiap produk BUMDes dikelola bersama masyarakat, meskipun tidak semua memiliki posisi dan porsi yang sama sesuai tingkat "civilized" atau seberapa berdaya masing-masing individu. Segmentasi dalam konteks ini menjadi gambaran division of role atau pembagian peran sesuai kemampuan, bukan sebuah dominasi golongan masyarakat tertentu. Kelompok masyarakat seperti anggota PKK terlibat aktif sebagai pengelola SWADESA, begitu pula sebagian petani yang bergabung dalam program AGRO dan pengolahan tamanu oil; para pegiat lingkungan, ibu rumah tangga juga berperan aktif dalam pengolahan sampah (KUPAS) dan pengelolaan bank sampah; beberapa warga dengan keterampilan khusus juga dapat menjadi pengolah R-UCO; serta para pemuda yang aktif mengelola Kampung Mataraman. Di Desa Panggungharjo, kapasitas sosial dan lingkungan telah dikelola dengan sangat baik. Pemimpin desa mampu menciptakan lingkungan peradaban yang baik, meningkatkan kesadaran akan urgensi partisipasi masyarakat, termasuk dalam memajukan desa melalui BUMDes berdasar atas prinsip-prinsip kooperatif, partisipatif, dan emansipatif (Faedlulloh, 2018: 13).

\section{Pengembangan Model dan Tahapan Desa Inovatif}

Inovasi desa dan desa inovatif, jika dimaknai secara utuh memiliki relasi yang sangat erat, yaitu desa inovatif hanya dapat terbentuk dari inovasi desa yang dikelola dengan apik. Mengacu pada Pedoman PID (Sumpeno, et.al., 2017: 5), definisi desa inovatif dalam artikel ilmiah ini adalah desa (sebagai entitas sosial) yang mampu mengenali dan mengatasi serta memanfaatkan teknologi canggih atau cara-cara baru untuk mengatasi masalah dan meningkatkan perekonomiannya dengan cara menggunakan teknologi yang ada di sekitar lingkungannya secara mandiri. Desa inovatif merupakan penghujung dari sebuah proses inovasi desa yang ideal. Sebuah desa yang inovatif diharuskan mampu mengembangkan inovasi desa yang berbasis kelembagaan, jejaring, dan interaksi. Desa Panggungharjo telah memenuhi semua elemen untuk menjadi sebuah desa inovatif. Berikut peneliti sajikan analisis enam unsur desa inovatif yang dimiliki oleh Desa Panggungharjo (Darmoko, 2015: 202-203).

Embrio inovasi, dimaknai sebagai bibit atau cikal bakal lahirnya inovasi, baik sebagai produk, kebijakan, sistem, proses, atau metode. Embrio inovasi berupa ide/gagasan inovasi dapat dikembangkan secara mandiri oleh individu/kelompok bersumber dari internal maupun eksternal. Embrio inovasi yang baik tentu berasal dari lingkungan internal organisasi, artinya, ide atau gagasan inovasi bersifat murni dari individu/kelompok di lingkungan organisasi berada sesuai dengan kebutuhan inovasi organisasi. Desa Panggungharjo berhasil mengembangkan embrio inovasi dari internal organisasi melalui inisiatif dari kepala desa. Embrio inovasi mencakup ide pembentukan BUMDes hingga digitalisasi inovasi pelayanan masyarakat yang telah dirintis pada tahun 2012. 
Kelembagaan inovasi, diartikan sebagai kekuatan utama inovasi. Artinya, inovasi yang ideal harus didukung oleh pembentukan dasar hukum inovasi, struktur pengelola inovasi, pembagian peran dan wewenang serta kejelasan alur tanggung jawab. Penguatan kelembagaan inovasi bertujuan untuk menjaga keberlanjutan dan kemanfaatan dari sebuah inovasi. Kelembagaan inovasi di Desa Panggungharjo dibentuk dengan perencanaan yang sangat matang melalui pembentukan BUMDes, Badan Pelaksana Jaring Pengaman Sosial (Bapel JPS), Lembaga Mediasi Desa (LMD), Lembaga Pengelola Desa Budaya Bumi Panggung, Lembaga Pengelola Sistem Informasi Desa, Sanggar Anak Desa, Dewan Masjid Desa, serta Forum Pengurangan Risiko Bencana, dan sejumlah lembaga desa lainnya (Media Indonesia, 2019).

Jejaring inovasi, merujuk pada interaksi antar stakeholder dalam sebuah lingkungan inovasi. Jejaring inovasi bergantung pada hubungan (kelembagaan) pengelola inovasi dan hubungan para pemangku kepentingan di luar lingkungan inovasi termasuk pengguna inovasi. Pemerintah Desa Panggungharjo mampu menciptakan dan mengelola jejaring inovasi melalui kerja sama lintas sektor dan aktor, yaitu dengan pemerintah dan nonpemerintah sebagai bagian dari quintuple helix.

Penguatan budaya inovasi, upaya pembiasaan berpikir dan bertindak inovatif dalam kehidupan sehari-hari, sebagai gaya hidup pemerintah, BUMDes, dan masyarakat desa. Continuous improvement terhadap produk inovasi, diversifikasi layanan Sistem Informasi Desa, pengembangan bisnis BUMDes, gebyar desa merupakan contoh upaya penguatan budaya inovasi di Desa Panggungharjo. Intervensi kemajuan IPTEK dan penyerapan isu global, diwujudkan melalui pengembangan Sistem Informasi Desa, dukungan pencapaian sustainable development goals melalui pengelolaan BUMDes dan pelestarian kearifan lokal melalui wisata budaya dan pemberdayaan masyarakat.

Selain unsur-unsur di atas, sebuah desa inovatif memiliki model desa inovatif yang dikembangkan melalui dua pendekatan, top-down dan bottom-up, yang di dalamnya terdapat empat peranan, yaitu, pelaku utama/innovator; regulator dan pembina; pendukung teknis; dan pendukung non-teknis (Suripto, 2016: 182). Selanjutnya, model desa inovatif dengan pendekatan top-down dan bottom-up dapat dilihat dalam gambar 3. 


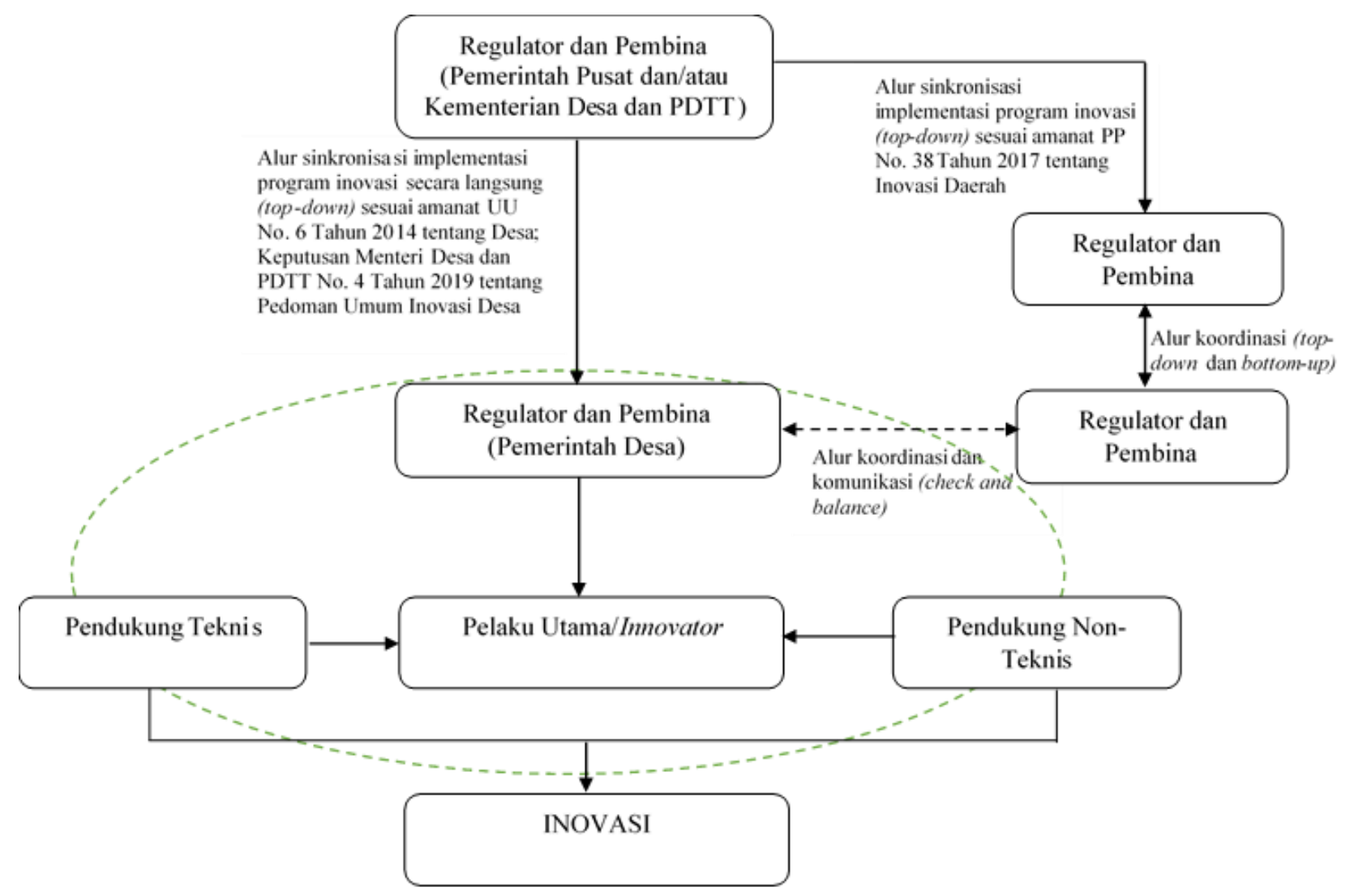

Gambar 3.

Model Desa Inovatif (Sumber: modifikasi "Pengembangan Model Desa Inovatif Kombinasi Top-Down dan Bottom-Up Innovation Model” (Suripto, 2016: 182)

Berdasarkan hasil telaah peneliti, pengembangan desa inovatif terdiri dari tujuh tahapan, antara lain; (1) identifikasi potensi sumber daya alam, sosial budaya, permasalahan, tantangan dan peluang di bidang pengembangan infrastruktur, sarana prasarana, teknologi; (2) identifikasi dan peningkatan kapasitas politik dan kepemimpinan; kapasitas proses dan birokrasi; dan kapasitas sosial dan lingkungan yang dimiliki desa; (3) menyusun perencanaan desa untuk jangka pendek, menengah, dan panjang, seperti Rencana Pembangunan Jangka Menengah Desa, Rencana Strategis Desa, dan Rencana Kerja Pemerintah Desa; (4) melaksanakan Program Prioritas Desa Nasional yang telah disusun oleh Kementerian Desa dan PDTT, sebagai contoh pengembangan Prukades, Embung Desa, BUMDes, dan Sorga Desa disesuaikan dengan kebutuhan dan kemampuan desa; (5) melakukan koordinasi, membangun jejaring dengan stakeholder seperti akademisi, sektor bisnis, masyarakat, dan media; (6) menerapkan model inovasi sesuai kebutuhan dan potensi desa berbasis reinforcement model atau replication model; (7) meningkatkan inovasi dengan mengembangan model inovasi Quintuple Helix. Lebih lanjut, skema/tahapan pengembangan desa inovatif dapat dilihat dalam gambar 4. 


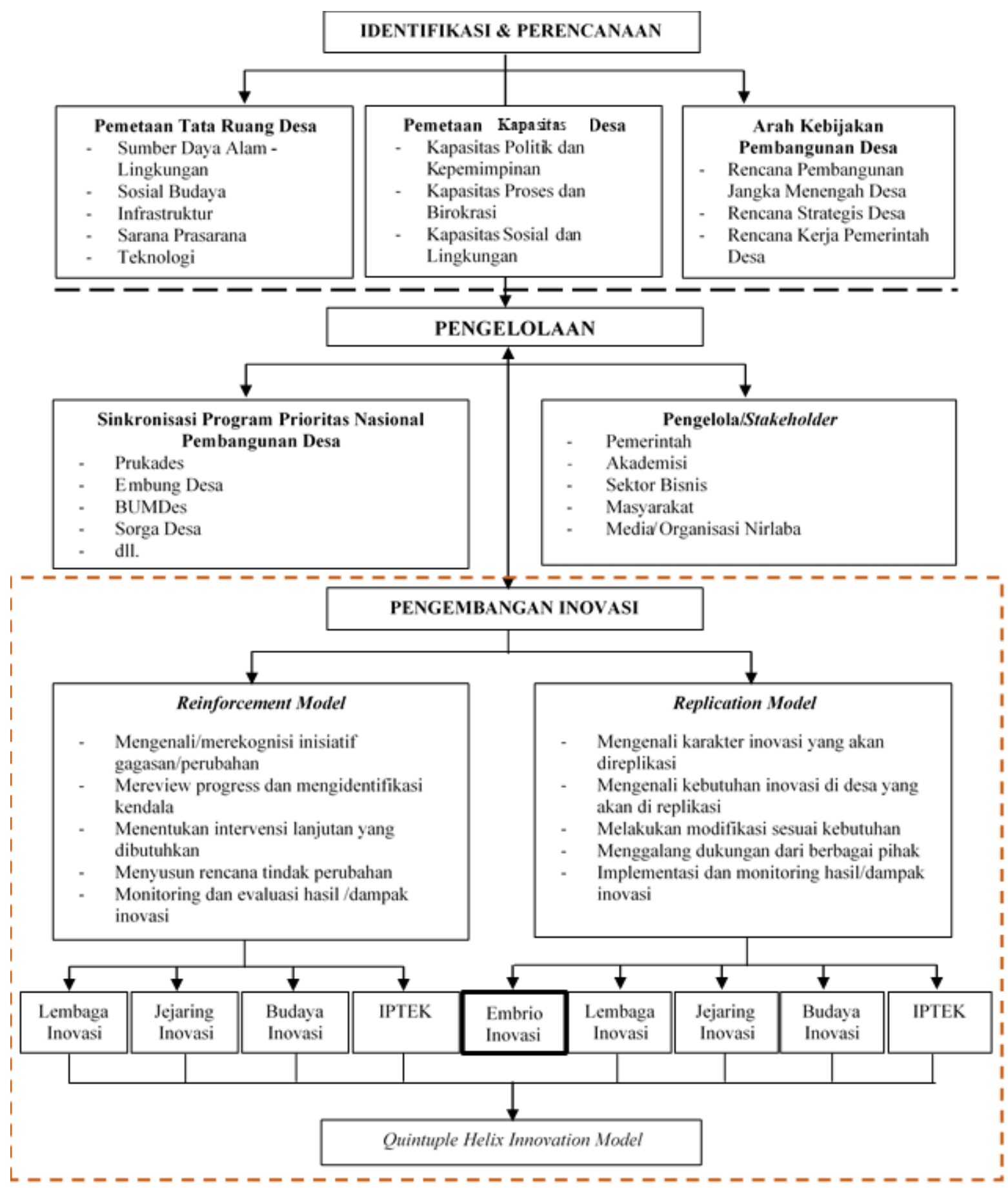

Gambar 4.

Skema/Tahapan Pengembangan Desa Inovatif Model Pengembangan Desa Inovatif

(Sumber: hasil telaah peneliti, 2020)

\section{E. PENUTUP}

Artikel ini memperkuat argumen model inovasi quintuple helix, membantah model inovasi linier, dan mendukung pelibatan helix lingkungan alami sebagai bagian integral dari inovasi. Artikel studi kasus ini menunjukkan bahwa modifikasi model inovasi strengthening model dan quintuple helix innovation model terbukti efektif dalam pengembangan inovasi desa. Artikel ini juga membuktikan bahwa desa dapat benar-benar mandiri sesuai amanat 
UU No. 6 Tahun 2014 Tentang Desa, PP No. 38 Tahun 2017 Tentang Inovasi Daerah, dan Keputusan Menteri Desa dan PDTT No. 83 Tahun 2017 Tentang Penetapan Pedoman Umum Program Inovasi Desa.

Temuan menarik dari artikel ini adalah bahwa secara formal, pedoman program inovasi desa diatur pada tahun 2017, tetapi, sejak tahun 2013, Desa Panggungharjo telah mampu menciptakan embrio inovasi, mendorong penguatan kelembagaan inovasi dan budaya inovasi, pembentukan jejaring inovasi (interaksi antar pelaku kepentingan), dan pemanfaatan IPTEK serta responsivitas atas isu-isu global. Hal tersebut menjadi sebuah fenomena yang membantah opini mainstream tentang ketidakmampuan desa dalam mengembangkan inovasi melalui pemanfaatan potensi lokal.

Model inovasi quintuple helix di Desa Panggungharjo memberikan gambaran bahwa alur inovasi digerakkan oleh peran helixes/subsistem utama inovasi, yaitu pemerintah desa, industri, universitas, masyarakat, dan lingkungan alami desa. Secara teknis, bentuk peran masing-masing helix sangat beragam, tidak semua helix memiliki porsi peran yang sama, dan tidak semua helix berperan sebagai penghasil inovasi. Kondisi demikian menggambarkan hubungan complementary dalam pengembangan inovasi. Di samping itu, dapat disimpulkan bahwa melalui pelibatan unsur lingkungan alami dalam model inovasi, Desa Panggungharjo dapat benar-benar berhasil mewujudkan sustainable development pada konteks kewilayahan.

Belajar dari Desa Panggungharjo, artikel studi kasus ini membuktikan bahwa tidak semua permasalahan desa bersifat restraining dan menyebabkan diskontinuitas inovasi. Keterbatasan kapasitas internal desa yang selama ini menghambat proses pembangunan dan inovasi desa dapat diatasi dengan pelibatan helix eksternal, yaitu industri dan universitas sebagai penghasil inovasi. Dalam konteks ini, melalui pemanfaatan dana desa, desa harus mampu menyikapi persoalan mendasar di bidang teknologi informasi dan sumber daya manusia sebagai tantangan dan peluang untuk terus berinovasi.

Terdapat tiga faktor utama penentu keberhasilan inovasi desa, yaitu kapasitas politik dan kepemimpinan; kapasitas proses dan birokrasi; dan kapasitas sosial dan lingkungan. Kepala Desa Panggungharjo memiliki kapasitas politik dan kepemimpinan yang sangat baik sehingga mampu memaksimalkan potensi birokrasi desa dan menumbuhkan kapasitas sosial dan lingkungan pada level masyarakat. Secara politis, Kepala Desa Panggungharjo mampu menggunakan sumber kekuasaan dengan sangat bijak hingga berhasil mewujudkan kemandirian dan kemajuan desa. Artikel ini melihat bahwa kendali atas tiga kapasitas inovasi desa didominasi oleh figur Kepala Desa.

Di lain sisi, persoalan sentralisasi sumber kapasitas inovasi dapat memicu permasalahan bagi desa. Bukan tidak mungkin, hegemoni tokoh politik desa akan menjadi hambatan bagi kemajuan inovasi, terlebih jika kepala desa sebagai pemimpin inovasi tidak lagi terlibat secara aktif memimpin/memantau perkembangan inovasi. Sebagai bentuk kontribusi ilmiah dari artikel ini, penulis menyusun beberapa rekomendasi yang dinilai layak untuk menjadi pertimbangan.

Pertama, pemerintah desa harus membangun sistem inovasi didukung oleh lingkungan inovasi yang kondusif dan melibatkan seluruh helix inovasi dengan porsi peran yang seimbang. Pemberdayaan masyarakat desa melalui pendampingan fasilitator harus terus dilakukan agar masyarakat dapat memiliki peran sebagai penghasil inovasi, bukan hanya pengguna inovasi. Berbagai program pemerintah pusat seperti Akademi Desa 4.0, Program Inovasi Desa, serta upaya kerja sama melalui skema CSR dapat terus dikembangkan. Langkah ini krusial untuk memastikan lingkungan inovasi tetap kondusif meskipun terjadi pergantian rezim kepemimpinan. 
Kedua, untuk menjamin kemajuan dan keberlanjutan serta pemanfaatan maksimal BUMDes Panggung Lestari, Pemerintah Desa Panggungharjo dapat melibatkan masyarakat sebagai pemilik dan pengelola BUMDes. Skema kepemilikan dan pengelolaan bisa seperti koperasi, diatur persentase antara "saham" yang dimiliki pemerintah desa dan warga desa. Skema ini memungkinkan optimalisasi potensi BUMDes sebagai ruang belajar bagi warga desa untuk berdemokrasi ekonomi (Faedlulloh, 2018: 15). Melalui langkah tersebut, penulis optimis bahwa modal sosial akan lebih kuat sehingga BUMDes dapat melembaga secara ekonomi dan sosial.

Ketiga, Pemerintah Desa Panggungharjo harus terus menjalin kerja sama baik teknis maupun administratif dengan lembaga supra desa. Pemerintah lokal pada level kecamatan, kabupaten hingga provinsi dapat berperan sebagai helix pemerintah, mengingat lembaga supra desa tersebut memiliki peran krusial, khususnya dalam pelaksanaan dan penyesuaian perencanaan dan evaluasi pembangunan desa. Dalam konteks ini, program inovasi desa harus linier dengan rencana pembangunan lembaga supra desa sehingga dampak dari inovasi desa dapat berimbas pada perkembangan ekonomi wilayah/regional secara kontinyu.

\section{DAFTAR PUSTAKA}

Alam, A. S., \& Mamu, A. (2016). Isu-Isu Strategis dalam Pembangunan Desa di Kecamatan Pitumpanua Kabupaten Wajo. Jurnal Ilmu Pemerintahan, 9(114), 95-102.

Andari, N., \& Ella, S. (2019). Pengembangan Model Smart Rural Untuk Pembangunan Kawasan Perdesaan Di Indonesia Developing a Smart Rural Model for Rural Area Development in Indonesia. Jurnal Borneo Administrator, 15(1), 41-58. https://doi.org/10.24258/jba.v15i1.394

Baber, Z. (2001). Globalization and Scientific Research: The emerging Triple Helix Of State-Industry-University Relations in Japan and Singapore. Bulletin of Science, Technology and Society, 21(5), 401-408. https://doi.org/10.1177/027046760102100509

Baccarne, B., Logghe, S., Schuurman, D., Marez, L. De, \& Shusterman, N. (2016). Governing Quintuple Helix Innovation: Urban Living Labs and. Technology Innovation Management Review, 6(3), 22-30. Retrieved July, $12^{\text {th }} 2020$ from www.timreview.ca

Bakti, H. S. (2018). Identifikasi Masalah dan Potensi Desa Berbasis Indek Desa Membangun (Idm) di Desa Gondowangi Kecamatan Wagir Kabupaten Malang. Wiga: Jurnal Penelitian Ilmu Ekonomi, 7(1), 1-14. https://doi.org/10.30741/wiga.v7i1.331

Baxter, P., Susan Jack, \& Jack, S. (2008). Qualitative Case Study Methodology: Study Design and Implementation for Novice Researchers. The Qualitative Report Volume, 13(4), 544-559. https://doi.org/10.2174/1874434600802010058

Bungin, B. (2013). Burhan Bungin, Metodologi Penelitian Sosial dan Ekonomi. Jakarta: Kencana Prenada Media Group.

Caduff C., S. F. \& W. T. (2010). Art and Artistic Research. Wälchli Zurich University of the Arts, Scheidegger and Spiess.

Carayannis, E. G., Barth, T. D., \& Campbell, D. F. (2012). The Quintuple Helix Innovation Model: Global Warming as a Challenge and Driver for Innovation. Journal of Innovation and Entrepreneurship, 1(1), 2. https://doi.org/10.1186/2192-5372-1-2

Carayannis, E., \& Grigoroudis, E. (2016). Quadruple Innovation Helix and Smart Specialization: Knowledge Production and National Competitiveness. Foresight and STI Governance, 10(1),31-42. https://doi.org/10.17323/1995-459x.2016.1.31.42

CELAC. (2017). Innovation for Sustainable Rural Sustainable Rural Development: Towards 
A theoretical Framework. Retrieved July, 12 2020 from https://www.fao.org/3/ai7769e.pdf

Darmoko, P. D. (2015). Potensi Desa Inovasi di Kabupaten Pemalang. Madaniyah, 2(9), 198-211. $\quad$ Retrieved $\quad$ July, $12^{\text {th }} \quad 2020$ from https://media.neliti.com/media/publications/195105-ID-laporan-penelitian-potensidesa-inovasi.pdf

Delman J.and Madsen S. T. (2007). Nordic "Triple Helix" Collaboration in Knowledge, Innovation and Business in China and India: a Preliminary Study. NIAS Press.

European Commission. (2012). Guide to Research and Innovation Strategies for Smart Specialisation (RIS 3).

Faedlulloh, D. (2018). BUMDes dan Kepemilikan Warga: Membangun Skema Organisasi Partisipatoris. Journal of Governance, 3(1), 1-17. https://doi.org/10.31506/jog.v3i1.3035

García-terán, J., \& Skoglund, A. (2019). A Processual Approach for the Quadruple Helix Model: the Case of a Regional Project in Uppsala. 1272-1296.

Gibbons M., Limoges C., Nowotny H., Schwartzman S., S. P. and T. M. (1994). The new production of knowledge - The Dynamics of Science and Research in Contemporary Societies, . London, UK: SAGE Publications.

Grundel, I., \& Dahlström, M. (2016). A Quadruple and Quintuple Helix Approach to Regional Innovation Systems in the Transformation to a Forestry-Based Bioeconomy. Journal of the Knowledge Economy, 7(4), 963-983. https://doi.org/10.1007/s13132016-0411-7

Hadi, W. A. (2019). Asa Kemandirian Desa; Yogyakarta.

Jaelani, A. (2019). The Triple Helix as a Model for Innovation of Higher Education: Analysis of Institutional Logic in Entrepreneurship and Economic Development. Munich Personal RePEc Archive, (95752), 121-138.

Jamaluddin, Y., Sumaryana, A., Rusli, B., \& Buchari, R. A. (2018). Analisis Dampak Pengelolaan dan Penggunaan Dana Desa terhadap Pembangunan Daerah. JPPUMA: Jurnal Ilmu Pemerintahan Dan Sosial Politik Universitas Medan Area, 6(1), 14. https://doi.org/10.31289/jppuma.v6i1.1520

Kolehmainen, J., Irvine, J., Stewart, L., Karacsonyi, Z., Szabó, T., Alarinta, J., \& Norberg, A. (2016). Quadruple Helix, Innovation and the Knowledge-Based Development: Lessons from Remote, Rural and Less-Favoured Regions. Journal of the Knowledge Economy, 7(1), 23-42. https://doi.org/10.1007/s13132-015-0289-9

Leydesdorff, L., \& Etzkowitz, H. (1998). Triple Helix of Innovation: Introduction. Science and Public Policy, 25(January 1998). https://doi.org/10.1093/spp/25.6.358

Madureira, L., \& Torre, A. (2019). Innovation Processes in Rural Areas. Wiley, 11(2), 213218. https://doi.org/10.1111/rsp3.12215

Media Indonesia. (2019). Wahyudi Anggoro Hadi Mengharamkan Politik Uang. Retrieved $\begin{array}{llllll}\text { June } 9, \quad 2020, & \text { Retrieved June, } & 20^{\text {th }} & 2020 & \text { from }\end{array}$ https://mediaindonesia.com/read/detail/226361-wahyudi-anggoro-hadimengharamkan-politik-uang

Mehta, M. (2003). Regulating Biotechnology and Nanotechnology in Canada: a PostNormal Science Approach for Inclusion of the Fourth Helix", In: Z. Baber and H. Klondker (Eds.) The Triple Helix. New York: State University of New York Press.

Muluk, M. R. K. (2008). Knowledge Management: Kunci Sukses lnovasi Pemerintahan Daerah (1st ed.). Malang: Bayu Media.

Neth, B., Sam Ol, R., \& Yokohari, M. (2013). Development Without Conformity: Impacts 
of Large-Scale Economic Development on Indigenous Community Livelihoods in Northeastern Cambodia. International Journal of Environmental and Rural Development, 4(2), 82-88.

OECD. (2018). Enhancing Rural Innovation (11th OECD Rural Development Conference). (April), 19. Retrieved July, 12 ${ }^{\text {th }} 2020$ from https://www.oecd.org/rural/ruraldevelopment-conference/outcomes/Proceedings.pdf

Osborne, D. \& T. G. (1993). Reinventing Bureaucracy: How the Entrepreneurial Spirit is Transforming the Public Sector. New York: Plume.

Patel, L. (2015). Social Welfare and Social Development (2nd Edition). in Oxford University Press Southern Africa (Pty) Limited. Retrieved June, 20 $0^{\text {th }} 2020$ from https://doi.org/10.15270/52-2-507

Pemerintah Desa Panggungharjo. (2018a). Berkat Hal Ini, Desa Panggungharjo Sukses Memajukan Kehidupannya - Panggungharjo. Retrieved June $10^{\text {th }}, 2020$, from http://www.panggungharjo.desa.id/3557-2/

Pemerintah Desa Panggungharjo. (2018b). Hadapi Era Disrupsi, FT Universitas Janabadra Tandatangani MoU dengan Pemerintah Desa Panggungharjo - Panggungharjo. Retrieved June $10^{\text {th }}, 2020$, from http://www.panggungharjo.desa.id/3419-2/

Pemerintah Desa Panggungharjo. (2019). Poltekkes Kemenkes Yogyakarta Resmikan Panggungharjo Sebagai Wilayah Binaan - Panggungharjo. Retrieved from http://www.panggungharjo.desa.id/poltekkes-resmikan-panggungharjo/

Pique, J. M., Berbegal-Mirabent, J., \& Etzkowitz, H. (2018). Triple Helix and The Evolution of Ecosystems of Innovation: The Case of Silicon Valley. Triple Helix, 5(1). https://doi.org/10.1186/s40604-018-0060-x

Praswati, A. N. (2017). Perkembangan Model Helix dalam Peningkatan Inovasi. Prosiding Seminar Nasional Riset Manajemen \& Bisnis 2017 Perkembangan Konsep Dan Riset E-Business di Indonesia, 690-705. Retrieved June, $20^{\text {th }} 2020$ from https://publikasiilmiah.ums.ac.id/bitstream/handle/11617/9022/sansetmab2017_15.pdf ?sequence $=1 \&$ isAllowed $=\mathrm{y}$

Prihatsanti, U., Suryanto, S., \& Hendriani, W. (2018). Menggunakan Studi Kasus sebagai Metode Ilmiah dalam Psikologi. Buletin Psikologi, 26(2), 126. https://doi.org/10.22146/buletinpsikologi.38895

Provenzano, V., Arnone, M., \& Seminara, M. R. (2016). Innovation in the Rural Areas and the Linkage with the Quintuple Helix Model. Procedia - Social and Behavioral Sciences, 223(September), 442-447. https://doi.org/10.1016/j.sbspro.2016.05.269

Purnamasari, H. (2018). Manajemen Pemerintahan Dalam Pembangunan. 3(1), 1-13. \begin{tabular}{llll} 
Retrieved $\quad$ June, & $10^{\text {th }}$ & 2020 & from \\
\hline
\end{tabular} https://journal.unsika.ac.id/index.php/politikomindonesiana/article/view/1407/1162

Purwanto \& Wahyuningsih. (2017). Inovasi Daerah Dalam Pembangunan Desa Berbasis Potensi Desa (Kajian Pengembangan Desa Inovasi Maos-lor, Kecamatan Maos, Kabupaten Cilacap). Mimbar Administrasi, 1(1), 11.

Pyburn \& Woodhill. (2015). Partnership and Value Creation in a Private Sector Innovation Initiative. In Dynamics of Rural Innovation: a Primer for Emerging Professionals. Royal Tropical Institute.

Sidik, F. (2015). Menggali Potensi Lokal Mewujudkan Kemandirian Desa. JKAP (Jurnal Kebijakan Dan Administrasi Publik), 19(2), 115. https://doi.org/10.22146/jkap.7962

Singh, S., \& Bhowmick, B. (2015). An Exploratory Study for Conceptualization of Rural Innovation in Indian Context. Procedia - Social and Behavioral Sciences, 207, 807815. https://doi.org/10.1016/j.sbspro.2015.10.171 
Sudirah. (2015). Modal Sosial dan Pemberdayaan Masyarakat Desa Wisata. Prosiding Seminar Nasional Fakultas Ilmu Sosial Dan Ilmu Politik, Universitas Terbuka UTCC, 26 Agustus 2015, (2001), 148-156.

Sugeng, P., Rachmawati, T., Yosefa, T. G., Herwanto, T. S., \& Wicaksono, K. W. (2017). Inovasi untuk MewujudkanDesa Unggul dan Berkelanjutan (1st ed.). Jakarta: FriedrichEbert-Stiftung Kantor Perwakilan Indonesia.

Sugiyono. (2013). Metode Penelitian Kuantitatif, Kualitatif dan R\&D. Bandung: Alfabeta.CV.

Suharyanto \& Sofianto, A. (2012). Innovative Model of Integrated Rural Development in Central Java. Bina Praja, $4(4)$, $251-260$. https://doi.org/https://doi.org/10.21787/jbp.04.2012.251-260

Sukarno, G. (2018). Memperkokoh Daya Saing Industri Kreatif Melalui Quintuple Helix, Kreatifitas Industri Dan Kapabilitas Industri. UNEJ E-Proceeding, 1-12. Retrieved June, $10^{\text {th }}$ from

https://jurnal.unej.ac.id/index.php/prosiding/article/download/9133/6116

Sulaksono, H. (2018). Roadblock Implementasi Peran Quadruple Helix. 366-381.

Sumpeno, E. a. (2017). Kementerian Desa Pembangunan Daerah Tertinggal dan \begin{tabular}{l|lllll} 
Transmigrasi & (Vol. 1). Retrieved June, $10^{\text {th }}$ from
\end{tabular} https://kemendesa.go.id/berita/view/detil/3244/ini-tiga-kebijakan-penggunaan-danadesa-selama-covid-19\%0Ahttp://kemendesa.go.id/view/detil/1663/bumdes-akantopang-lumbung-ekonomi-desa

Suripto. (2016). Pengembangan Model Desa Inovatif Kombinasi Top-Down dan Bottom-Up Innovation Model. In A. Suripto; Taufik (Ed.), Buku Seri Inovasi Administrasi Negara Volume 2 Pengembangan Model dan Story Inovasi Tata Kelola Pemerintahan dan Pelayanan Publik (I, pp. 161-187). http://repositorio.unan.edu.ni/2986/1/5624.pdf

Tubagus Furqon Sofhani, V. N. (2017). Pengembangan Wilayah Berbasis Quadruple Helix : Analisis Jaringan Antar. 17-26.

Utomo, T. W. W. (2017). Model Inovasi Desa Untuk Optimalisasi Dana Desa. Paparan Laboratorium Inovasi LAN.

Widjajani, W., Fajarwati, A., Hidayat, A., \& Haryadi, D. (2018). Quadruple Helix Innovation Model for Rural Development: The Case of Sukaraja Tourist Village in Indonesia. $\quad$ Sosiohumanitas, $20(2), \quad 1-10$. https://doi.org/10.36555/sosiohumanitas.v20i2.106

Yawson, R. M. (2012). The Ecological System of Innovation: a New Architectural Framework for a Functional Evidence-Based Platform for Science and Innovation Policy. SSRN Electronic Journal, 1-16. https://doi.org/10.2139/ssrn.1417676 